\title{
Estimation of greenhouse gas emissions: An alternative approach to waste management for reducing the environmental impacts
} in Myanmar

\author{
Maw Maw Tun ${ }^{1,2^{\dagger}}$, Dagmar Juchelková ${ }^{1}$ \\ ${ }^{1}$ Department of Energy Engineering, VŠB-Technical University of Ostrava, 17. Listopadu 15, Ostrava-Poruba, 70833, Czech Republic \\ ${ }^{2}$ Department of Mechanical Engineering, Government Technical Institute (Mawlamyine), Main Road, MMR011001, Mawlamyine, Mon State, Myanmar
}

\begin{abstract}
Along with growing population and economic development, increasing waste generation rates in developing countries have become a major issue related to the negative impacts of waste management on the environment. Currently, the business-as-usual waste management practices in Myanmar are largely affecting the environment and public health. Therefore, this study developed an alternative approach to waste management for reducing the environmental impacts in Myanmar by highlighting the greenhouse gas (GHG) emissions from business-as-usual practices and three proposed scenarios during 2018-2025. The calculation methods of the Intergovernmental Panel on Climate Change and Institute for Global Environmental Strategies were used for estimating the GHG emissions from waste management. It was estimated that the current waste management sector generated approximately 2,000 gigagrams of $\mathrm{CO}_{2}$-eq per year in 2018, trending around 3,350 $\mathrm{Gg}_{\mathrm{g}}$ of $\mathrm{CO}_{2}$-eq per year in 2025. It was also observed that out of the proposed scenarios, Scenario-2 significantly minimized the environmental impacts, with the lowest GHG emissions and highest waste resource recovery. Moreover, the GHG emissions from business-as-usual practices could be reduced by $50 \%$ by this scenario during 2018-2025. The target of the similar scenario could be achieved if the local government could efficiently implement waste management in the future.
\end{abstract}

Keywords: Environmental impacts, Greenhouse gas emissions, Waste disposal, Waste generation, Waste management

\section{Introduction}

Myanmar is a developing country in South East Asia, bordered by China, Bangladesh, India, Thailand and Laos PDR. Myanmar is composed of seven states and seven regions. It covers an area of around 677,000 square kilometers. According to the Worldometer 2018 Report [1], Myanmar has the total population of over 53 million residents in 2018, trending around 57 million in 2025. The annual population growth rate is approximately $0.91 \%$ in 2018 . The average population density of the country is about 82 residents per square kilometer and about $36.8 \%$ of the population resides in urban area. Per capita gross domestic product (GDP) of Myanmar accounts for around 1,350 US dollars in 2018 [2]. Naypyidaw is the capital city of the country while Yangon and Mandalay are the major commercial cities.
The trends of the population growth and per capita GDP of Myanmar are presented in Fig. 1. In Myanmar, the rural population was approximately twice as high as the urban population by 2018. However, since the year of 2010, the annual urban population of Myanmar has been gradually increased by approximately $2 \%$ due to the regular economic development of the country and per capita GDP growth. Therefore, the urban population has grown up from approximately 15 million in 2010 to 23 million in 2025 . As a result, the urban population will be around $40 \%$ of the total population by 2025 .

In Myanmar, the provision of waste collection services, management activities and initiation of 3Rs (Reduce, Reuse and Recycle) practices are extensively undertaken by responsible organizations independently [4]. Municipal waste collection systems in Myanmar cities can largely be characterized as labor intensive, relying on the use of both manual workers and non-specialized

Received October 17, 2018 Accepted December 11, 2018

${ }^{\dagger}$ Corresponding author

Email: maw.maw.tun.st@vsb.cz

Tel: $+420-773287487$

ORCID: 0000-0002-6243-3982 


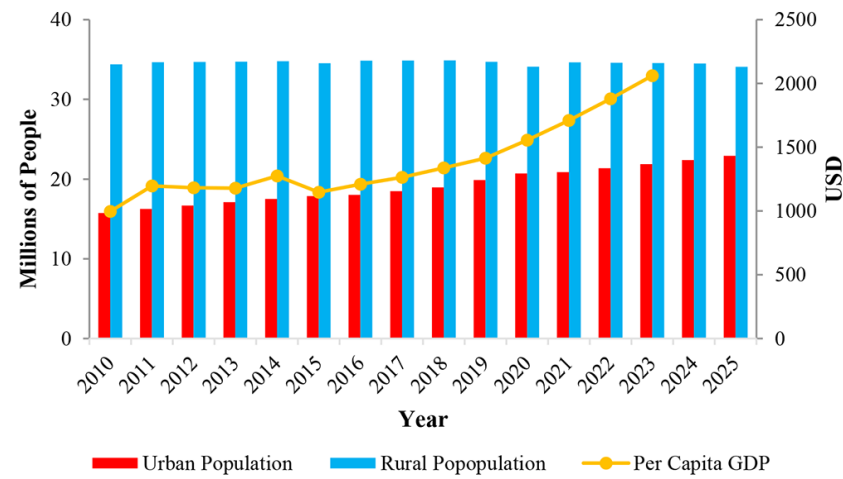

Fig. 1. Trends of population growth and per capita GDP of Myanmar [1-3].

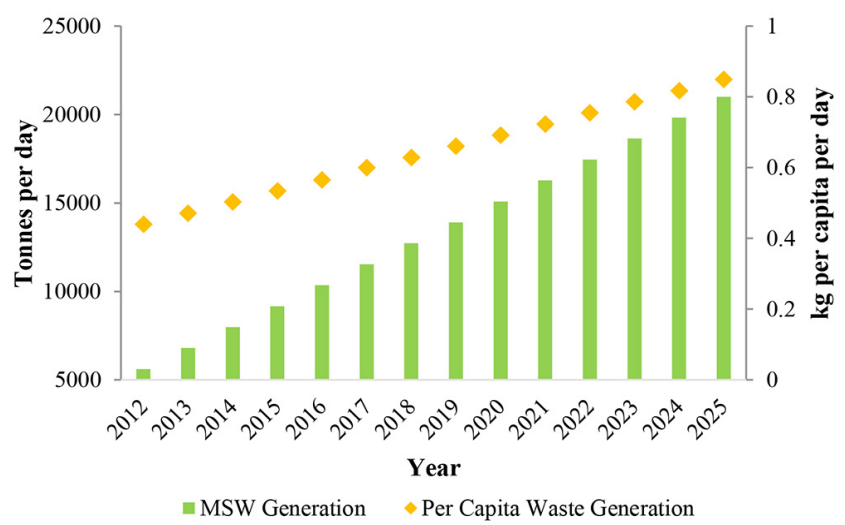

Fig. 2. Solid waste generation and per capita waste generation.

vehicles [5]. Waste collection methods in Myanmar account for door to door waste collection, bell ringing block collection, collection of waste from the kerb site bins, collection at street dump yards, collection at temporary storage system and sweeping the wastes on the road [5-7]. The collection efficiency of the major cities of Myanmar amounts to approximately 92\%. However, the average collection efficiency of the whole country is comparatively lower than that of the major cities, with around $45 \%$ in average [8]. The total waste generation rate of Myanmar accounted for approximately 13,000 tons per day, with 0.63 kilogram per capita per day in 2018 (Fig. 2). This rate might reach around 21,000 tons per day, with 0.85 kilogram per capita per day by 2025 . The composition of municipal solid waste (MSW) in Myanmar accounts for organic wastes (54\%), plastic (16\%), paper/cardboard (8\%), glass (7\%), metal (8\%) and others (7\%) (Fig. 3).The organic fraction in the major cities, particularly in Yangon and Mandalay is comparatively higher than that of the whole country.

Currently, open dumping is the major waste disposal method in Myanmar, with approximately $85 \%$ of the total waste disposal methods of the country. One incineration plant with a capacity of 60 tons of wastes per day [9] and one anaerobic digestion plant with 30 tons of organic wastes per day [5] have been built for energy recovery in the major cities of Myanmar. 3Rs activities have been widely practiced in the major cities of Myanmar but the recycling sector of the country is still in the development stage.

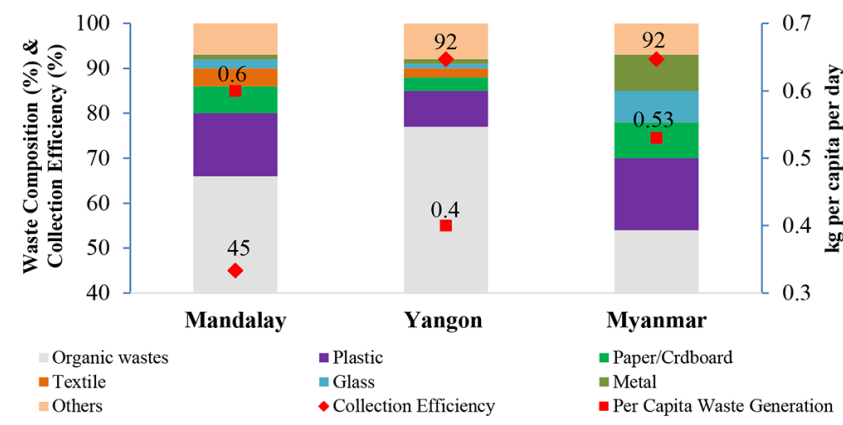

Fig. 3. Comparison of waste composition, collection efficiency and per capita waste generation in Myanmar and its two major cities [5, 8].

Informal sector for collecting the recyclables is common in Myanmar and only 86 tons of recyclables per d has been collected by the municipality of Yangon [5]. However, the recycling rate represents approximately only $2 \%$ of the total generated wastes of the country. The data about the recyclable rates of other cities have not been recorded yet.

According to the World Bank 2012 Report [8], waste generation rates might double over the next two decades in developing countries. Currently, waste management is a serious problem in low-income and middle-income South East Asian countries due to the environmental pollution from the landfills [10]. Mostly, the landfills in the Asian developing countries are open dumping or unmanaged landfilling types. Along with growing population, increasing per capita waste generation and economic growth, increasing waste generation rates in the developing countries have become a major issue related to waste management such as environmental pollution and climate change. The consequences of doing little or even nothing to address waste management can be very costly to society and to the economy overall [11]. Nowadays, the improper waste collection and treatment systems in Myanmar have been accelerating the negative impacts of MSW management on the environment and public health. Thein's study [12] highlighted the GHG emission potential from final waste disposal at open dumpsites in Myanmar during the year 2000-2020 in order to draw attention to the impacts of solid waste on the environment. Besides, the research study [13] also assessed the GHG emission potential from the future waste management of Yangon, the biggest city of Myanmar, for the year 2015-2025. However, as far as the authors are aware, the research study related to the MSW management system of Myanmar to tackle the environmental issues has not been conducted yet. Therefore, the present study aimed at proposing an alternative approach to MSW management for reducing the environmental impacts by highlighting the GHG emissions of MSW management sectors by business-as-usual practices and three proposed scenarios.

\section{Materials and Methods}

\subsection{Data Sources}

The data related to solid waste generation, waste composition and waste disposal methods were collated from the published 


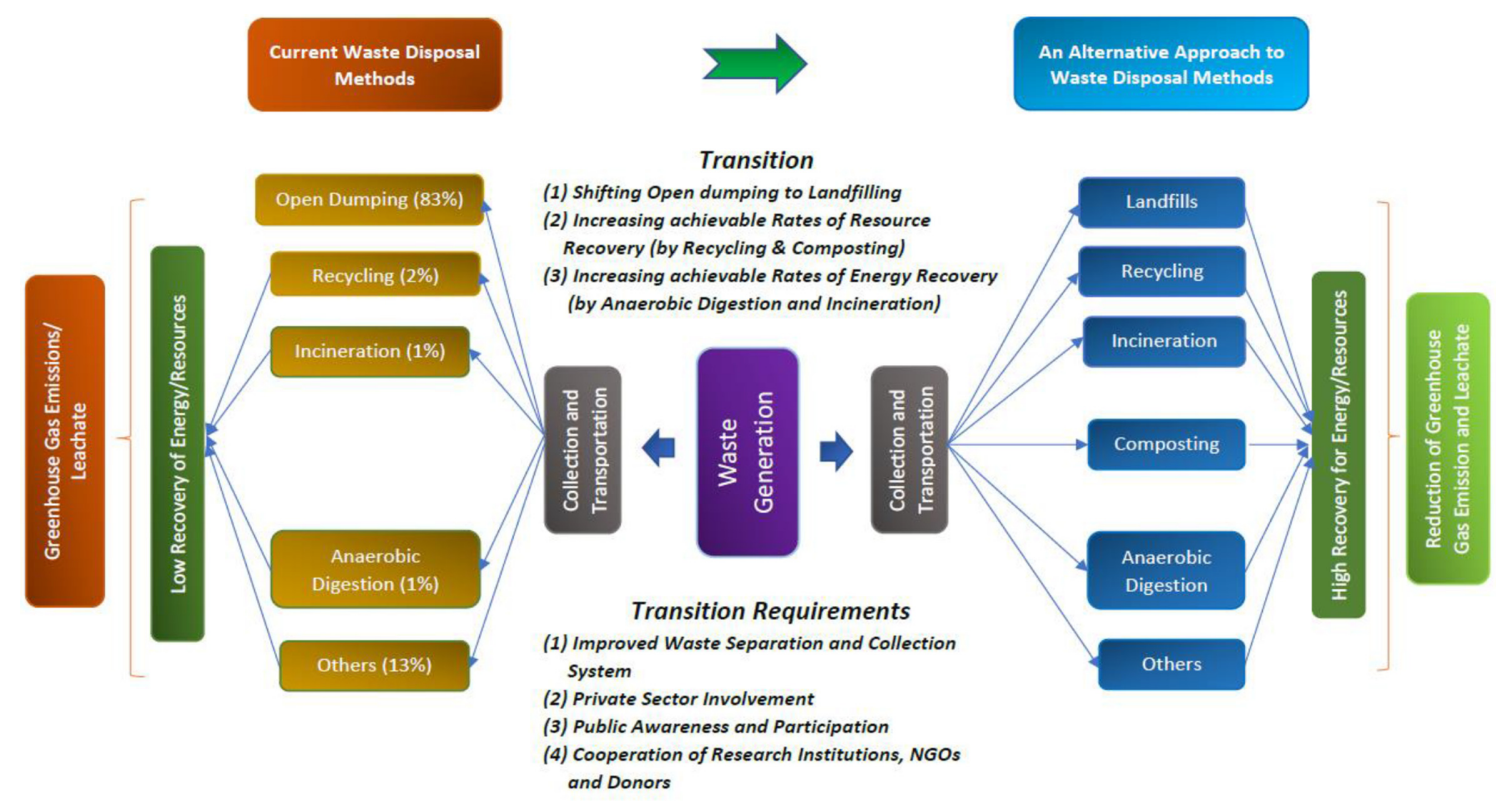

Fig. 4. Current process and an alternative approach to MSW management in Myanmar.

research papers and policy reports [5, 8, 10, 13, 14]. Since Myanmar is one of the low-income countries in Asia, the country specific data about waste management are not sufficiently available. Therefore, the data about solid waste generation and waste composition during 2018-2025 were derived from the World Bank 2012 report [8] (Table S1). Waste disposal methods were derived from the research paper [10] and Institute for Global Environmental Strategies (IGES) policy report [5]. A comparison of the current process and alternative approach to MSW management in Myanmar is described in Fig. 4.

\subsection{Considerations and Assumptions for the Proposed Waste Disposal Methods}

To make a comparison of the GHG emissions from the business-as-usual waste disposal methods, three hypothetical scenarios were proposed to develop the alternative waste disposal methods in Myanmar. Composition may change with time and season. However, waste composition in this study was considered uniform during 2018-2025 for ease of estimation since waste composition in most of the developing countries could change slowly due to the regular economic growth and changes in consumption patterns. The waste disposal methods from business-as-usual practices [14] and three scenarios were considered as shown in Fig. 5. Other waste disposal methods (others) account for animal feeding and reuse activities, illegal dumping and open burning.

\section{(a) Business-as-usual}

Business-as-usual was considered that the current MSW management in Myanmar would proceed in a normal practice or in the same way during the considered timeframe of the future (2018-2025).

\section{(b) Scenario-1}

Scenario-1 was considered that it was totally hard and un- realistic for developing countries to transform from open dumpsites to very costly waste to energy technologies in a short time. Instead, developing countries could increase the recycling rates by improving the separation work and more efficient waste collection system. Sanitary landfilling without gas collection system could be substituted for open dumping, as mostly practiced by Asian developing countries. Though landfilling could affect the environment, it was still considered as a reasonably improved step towards MSW management in the developing countries. As one example of the Asian developing countries, the recycling rates in Thailand amounted to 14\% as per the World Bank 2012 report [8]. Therefore, Myanmar could increase the current recycling rates up to $5 \%$ if efficiently managed.

\section{(c) Scenario-2}

Scenario-2 was considered if the high improvement of waste separation and collection could be made for composting process and more recycling rates in addition to the practices of Scenario-1. Composting was chosen because of three reasons: (a) in Myanmar, the majority of MSW composition constitutes organic wastes; (b) most composting methods could be easily processed by locally accessible technologies; (c) composting process has comparatively lower cost than the waste-to-energy technologies (anaerobic digestion and waste incineration, etc.). Besides, composting is also becoming one of the most popular waste management options in Asia [15].

\section{(d) Scenario-3}

Scenario-3 was considered if Myanmar could probably afford more percentages of waste-to-energy technologies (incineration and anaerobic digestion), but not in a big jump. It was just a regularly emerging step towards waste-to-energy technologies in addition to a combination of more recycling rates and composing process. Nowadays, in the developing Asia, there is a growing 


\section{Business-as-usual}

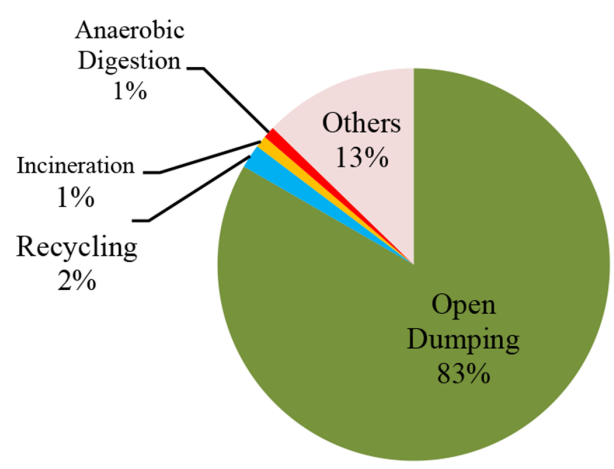

Scenario-2

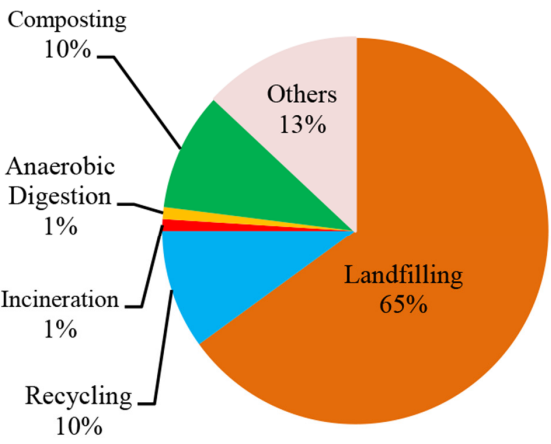

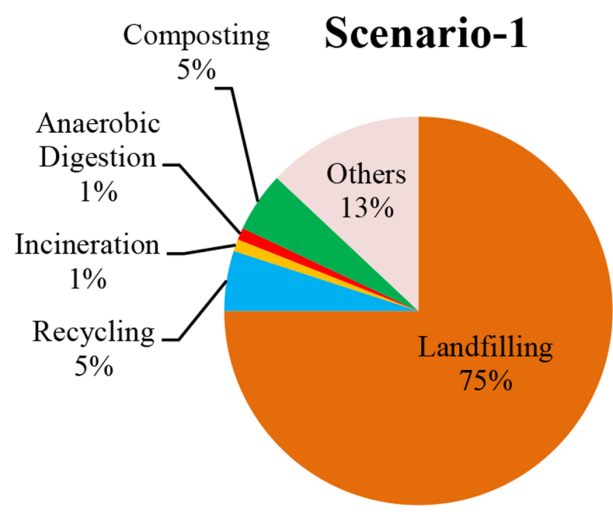

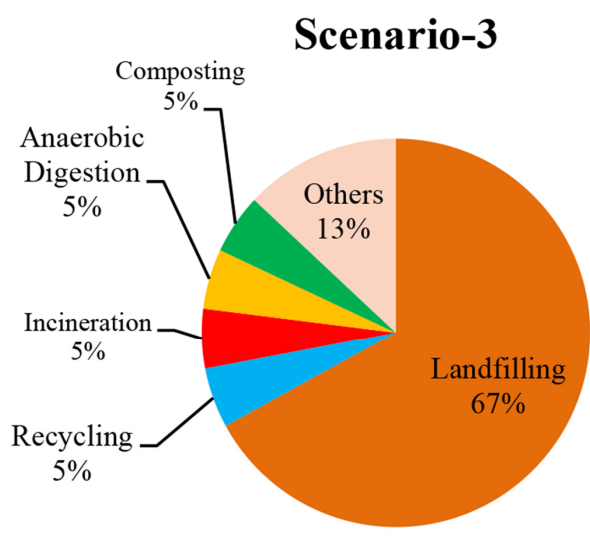

Fig. 5. Waste disposal methods related to business-as-usual and an alternative approach with three different scenarios during $2018-2025$.

interest for energy recovery from waste as a solution for the energy crisis and it also enables financial benefits via energy recovery [15].

The amount of the treated solid wastes related to business-as-usual and three hypothetical scenarios is attached in the supplementary table section (Table S2, Table S3, Table S4 and Table S5).

\subsection{Methods}

The technical methods for GHG emissions and avoidance from recycling sector, composting, anaerobic digestion, incineration and transportation have been well developed by IGES [15] to estimate GHG emissions from waste management in the Asian developing countries. Therefore, we deem these methods so useful to estimate GHG emission from waste management of Myanmar. Besides, the Intergovernmental Panel on Climate Change (IPCC) calculation method [16, 17] was used for estimating the GHG emissions from waste disposal at open dumping and landfills of Myanmar. Other waste disposal method (13\% of the total generated wastes) was not included in the GHG emission estimation because the study considered that there was only a little amount of GHG emissions from these disposal methods (mostly animal feeding and reuse activities, and partly illegal dumping and open burning).

\subsubsection{GHG emissions and avoidance from recycling}

The total net GHG emissions or avoidance from the recycling sector were estimated by the GHG emissions from recycling process of recyclable materials minus the GHG avoidance from the equivalent amount of material production from the virgin process of the recyclable materials and from landfilling of the recyclable materials. Then, based on the IGES GHG calculation methods [15], the total net GHG emissions from recycling were estiamated as described in Eq. (1) [13]:

$$
N G H G_{R}=\sum_{i=1}^{n}\left(E_{i}-\left(A_{i}+L_{i}\right)\right) R_{i}
$$

Where

$N G H G_{R}$ is the net GHG emission from the recycling sector $\left(\mathrm{kgCO}_{2}\right.$-eq per ton);

$E_{i}$ is GHG emission from recycling of component, $i$, in the recyclable materials $\left(\mathrm{kgCO}_{2}\right.$-eq per ton);

$A_{i}$ is the avoided GHG emission from equivalent amount of material production from virgin process of component, $i$, in the recyclable materials $\left(\mathrm{kgCO}_{2}\right.$-eq per ton);

$L_{i}$ is the avoided GHG emission from landfilling of component, $i$, in the recyclable materials ( $\mathrm{kgCO}_{2}$-eq per ton);

$R_{i}$ is the composition of component, $i$, in the recyclable materials (\%) and $n$ is the number of recyclable materials.

The GHG emissions and avoidance from recycling of the recyclable materials in Asian countries based on the country specific information in Thailand are attached in Table S6. 


\subsubsection{GHG emissions and avoidance from composting}

The total net GHG emissions or avoidance from composting sector were estimated by the GHG emissions from composting process minus the GHG avoidance from the replacement of the equivalent amount of chemical fertilizer use and from landfilling of the equivalent amount of organic wastes used for composting. Based on the IGES GHG calculation methods [15], the total net GHG emissions or avoidance from composting were estimated as described in the Eq. (2):

$$
\begin{aligned}
& N G H G_{C} \\
&= C_{\text {emission }}-C_{\text {avoidance }} \\
&= {\left[\left(\left(E_{C H 4} \times G W P_{C H 4}\right)+\left(E_{N 20} \times G W P_{N 20}\right)\right)\right] } \\
&-\left[\left\{\left(A C \times P C_{\text {Agr }}\right) \times\left(\left(E_{\text {fer } C O 2}\right)\right.\right.\right. \\
&\left.\left.+\left(E_{\text {fer CH4 }} \times G W P_{C H 4}\right)+\left(E_{\text {fer } N 20} \times G W P_{N 20}\right)\right)\right\} \\
&\left.+\left(G H G_{L F a v o i d a n c e}\right)\right]
\end{aligned}
$$

Where

$N G H G_{C}$ is the net GHG emission/avoidance from composting ( $\mathrm{kg} \mathrm{CO} 2$ per ton of waste);

$C_{\text {emission }}$ is the GHG emissions from composting process (kg $\mathrm{CO}_{2}$ per ton of organic waste);

$C_{\text {avoidance }}$ is the GHG avoidance from replacement of the equivalent amount of chemical fertilizer use and due to avoidance of landfilling of the equivalent amount of organic wastes used for composting ( $\mathrm{kg} \mathrm{CO}$ per ton of organic wastes);

$E_{\mathrm{CH} 4}$ is the emissions of methane $\left(\mathrm{CH}_{4}\right)$ during organic waste degradation ( $\mathrm{kg}$ of $\mathrm{CH}_{4}$ per ton of waste) (assumed as $4 \mathrm{~kg} \mathrm{CH}_{4}$ per ton of organic waste in wet basis given by IPCC, 2006);

$G W P_{C H 4}$ is the global warming potential of $\mathrm{CH}_{4}(21 \mathrm{~kg} \mathrm{CO}$ per $\mathrm{kg}$ of $\mathrm{CH}_{4}$ );

$E_{N 2 O}$ is the emissions of nitrous oxide $\left(\mathrm{N}_{2} \mathrm{O}\right)$ during waste degradation ( $\mathrm{kg}$ of $\mathrm{N}_{2} \mathrm{O}$ per ton of waste) $\left(0.3 \mathrm{~kg} \mathrm{~N} \mathrm{~N}_{2} \mathrm{O}\right.$ per ton of organic waste in wet basis given by IPCC, 2006);

$G W P_{N 2 O}$ is the global warming potential of $\mathrm{N}_{2} \mathrm{O}\left(310 \mathrm{~kg} \mathrm{CO}_{2}\right.$ per $\mathrm{kg}$ of $\mathrm{N}_{2} \mathrm{O}$ );

$A C$ is the amount of compost produced (ton of compost per ton of waste) (Approximately $120 \mathrm{~kg}$ of compost per ton of wastes);

$P C_{A g r}$ is the percentage of compost use for agricultural and gardening purpose (\%) (assumedly 100\% use);

$E_{\text {ferCO2 }}$ is the emissions of $\mathrm{CO}_{2}$ due to chemical fertilizer use (2,130 kg of $\mathrm{CO}_{2}$ per ton of compost);

$E_{\text {ferCH4 }}$ is the emissions of $\mathrm{CH}_{4}$ due to chemical fertilizer use (0.00338 kg of $\mathrm{CH}_{4}$ per ton of compost);

$E_{\text {ferN2O }}$ is the emissions of $\mathrm{N}_{2} \mathrm{O}$ due to chemical fertilizer use ( $0.0685 \mathrm{~kg}$ of $\mathrm{N}_{2} \mathrm{O}$ per ton of compost);

$G H G_{\text {LFavoidance }}$ is the GHG avoidance from landfilling of the equivalent amount of organic wastes used for composting calculated as per the Eq. (5) below.

Consideration for GHG emissions from fossil fuel consumptions for operation activities during composting process was not included for ease of estimation.

\subsubsection{GHG emissions and avoidance from incineration}

The total net GHG emissions or avoidance from incineration sector were estimated by the GHG emissions from combustion of wastes minus the GHG avoidance from the replacement of equivalent amount of conventional electricity and from landfilling of the equivalent amount of incinerated wastes. Then, based on the IGES GHG calculation methods [15], the total net GHG emission or avoidance from incineration were estimated as described in the Eq. (3):

$$
\begin{aligned}
N G H G_{I}= & I_{\text {emission }}-I_{\text {avoidance }} \\
= & {\left[\left(\sum_{i}\left(S W_{i} \times d m_{i} \times C F_{i} \times F C F_{i} \times O F_{i}\right)\right.\right.} \\
& \left.\times \frac{44}{12}+\left(E_{C H 4} \times G W P_{C H 4}\right)+\left(E_{N 20} \times G W P_{N 20}\right)\right] \\
& -\left[\left(G_{\text {electricity }} \times E_{C O 2}\right)+\left(G H G_{L F a v o i d n a c e}\right)\right]
\end{aligned}
$$

Where

$N G H G_{I}$ is the net GHG emission/avoidance from incineration ( $\mathrm{kg} \mathrm{CO}$ per ton of waste);

$I_{\text {emission }}$ is the GHG emissions from combustion of wastes $(\mathrm{kg}$ $\mathrm{CO}_{2}$ per ton of waste);

$I_{\text {avoidance }}$ is the GHG avoidance from replacement of equivalent amount of conventional electricity and due to avoidance of landfilling of the equivalent amount of incinerated wastes $(\mathrm{kg} \mathrm{CO}$ per ton of waste);

$S W_{i}$ is the total amount of solid waste of type $i$ (wet weight) incinerated ( $\mathrm{kg}$ per tonne of waste); $d m_{i}$ is the dry matter content in the waste (partially wet weight) incinerated;

$C F_{i}$ is the fraction of carbon in the dry matter (total carbon content), (fraction; 0.0-1.0);

$F C F_{i}$ is the fraction of fossil carbon in the total carbon, (fraction; $0.0-1.0$ ); $O F_{i}$ is the oxidation factor, (fraction; $0.0-100 \%$ );

$44 / 12$ is a conversion factor from $\mathrm{C}$ to $\mathrm{CO}_{2}$;

$i$ is the type of fossil based waste incinerated such as textiles, rubber and leather, plastics;

$E_{\mathrm{CH} 4}$ is the combustion emissions of $\mathrm{CH}_{4}\left(0.188 \mathrm{~kg}\right.$ of $\mathrm{CH}_{4}$ per ton of waste);

$G W P_{C H 4}$ is the global warming potential of $\mathrm{CH}_{4}\left(21 \mathrm{~kg} \mathrm{CO}_{2}\right.$ per $\mathrm{kg}$ of $\mathrm{CH}_{4}$ );

$E_{N 2 O}$ is the combustion emissions of $\mathrm{N}_{2} \mathrm{O}\left(.068 \mathrm{~kg}\right.$ of $\mathrm{N}_{2} \mathrm{O}$ per ton of waste);

$G W P_{N 2 O}$ is the global warming potential of $\mathrm{N}_{2} \mathrm{O}(310 \mathrm{~kg} \mathrm{CO}$ per $\mathrm{kg}$ of $\mathrm{N}_{2} \mathrm{O}$ );

$G_{\text {electricity }}$ is the generated electricity from incineration plant ( $\mathrm{kWh}$ per ton of waste) (assumed as $600 \mathrm{kWh}$ per ton of wastes [18]);

$E_{\mathrm{CO} 2}$ is the combustion emissions to generate one $\mathrm{kWh}$ of the electricity ( $\mathrm{kg}$ of $\mathrm{CO}_{2}$ per $\mathrm{kWh}$ ) (Assumedly $0.7 \mathrm{~kg}$ of $\mathrm{CO}_{2}$ per kWh [19]);

$G H G_{\text {LFavoidance }}$ is the GHG avoidance from landfilling of the same amount of incinerated wastes calculated as per the Eq. (5) below.

Consideration for GHG emissions from fossil fuel consumptions for operation activities during incineration process was not included for ease of estimation. Besides, the type of incineration was considered as the semi-continuous fluidized-bed incineration and the generation of the incineration plant was considered as electricity generation. 


\subsubsection{GHG emissions and avoidance from anaerobic digestion} The total net GHG emissions or avoidance from anaerobic digestion were estimated by the GHG emissions from the treatment of anaerobic digestion minus the GHG avoidance from the energy recovery from anaerobic digestion and from landfilling of the equivalent amount of organic wastes used for composting. Then, based on the IGES GHG calculation methods [15], the total net GHG emissions or avoidance from anaerobic digestion were estimated as described in the Eq. (4).

$$
\begin{aligned}
N G H G_{A D}= & A D_{\text {emission }}-A D_{\text {avoidance }} \\
= & {\left[\left(E_{C H 4} \times D M \times 1000 \times G W P_{C H 4}\right)\right] } \\
& -\left[\left(C_{\text {Biogas }} \times P_{C H 4} \times E C_{C H 4} \times E F_{C O 2}\right)\right] \\
& +\left(G H G_{\text {LFavoidance }}\right)
\end{aligned}
$$

Where

$N G H G_{A D}$ is the net GHG emission/avoidance from anaerobic digestion ( $\mathrm{kg} \mathrm{CO} \mathrm{CO}_{2}$ per ton of organic waste);

$A D_{\text {emission }}$ is the GHG emissions from the treatment of anaerobic digestion ( $\mathrm{kg} \mathrm{CO}_{2}$ per ton of organic waste);

$A D_{\text {avoidance }}$ is the GHG avoidance due to the energy recovery from anaerobic digestion and due to avoidance of landfilling of the equivalent amount of organic wastes used for anaerobic digestion $\left(\mathrm{kg} \mathrm{CO}_{2}\right.$ per ton of organic waste);

$E_{\mathrm{CH} 4}$ is the emissions of $\mathrm{CH}_{4}$ due to leakages ( $\mathrm{kg}$ of $\mathrm{CH}_{4}$ per $\mathrm{kg}$ of dry matter) (assumed as $2 \mathrm{~kg}$ of $\mathrm{CH}_{4}$ per ton of dry organic wastes);

$D M$ is the dry matter percentage in the influent (\%) (assumed as $20 \%$ ); 1,000 is the conversion factor to calculate dry matter content per ton of organic waste;

$G W P_{C H 4}$ is the global warming potential of $\mathrm{CH}_{4}(21 \mathrm{~kg} \mathrm{CO}$ per $\mathrm{kg}$ of $\mathrm{CH}_{4}$ );

$C_{\text {Biogas }}$ is the collected amount of biogas $\left(\mathrm{m}^{3}\right.$ per ton of organic waste) (assumed as $592 \mathrm{~m}^{3}$ per ton of dry mass);

$P_{C H 4}$ is the percentage of $\mathrm{CH}_{4}$ in biogas (\%) (Approximately $60 \%)$;

$E C_{C H 4}$ is the energy content of $\mathrm{CH}_{4}$ (M) per $\mathrm{m}^{3}$ ) (Approximately $37 \mathrm{MJ}$ per $\mathrm{m}^{3}$ );

$E F_{\mathrm{CO} 2}$ is the emission factor of $\mathrm{CO}_{2}$ by combustion of liquid petroleum gas (LPG) (kg of $\mathrm{CO}_{2}$ per M) (assumed as $0.063 \mathrm{~kg}$ of $\mathrm{CO}_{2}$ per MJ) (Despite having two types of substitution from biogas into thermal energy and electricity; in this study, it was assumed that LPG consumption was substituted by using biogas as thermal energy source);

$G H G_{\text {LFavoidance }}$ is the GHG avoidance from landfilling of the equivalent amount of organic wastes calculated as per the Eq. (5) below.

Consideration for GHG emissions from fossil fuel consumptions for operation actives during anaerobic digestion was not included for ease of estimation.

\subsubsection{GHG emissions from open dumping and landfills}

GHG emissions from waste disposal at open dumping and landfills were estimated based on the IPCC default methods since this approach is reasonably suitable for the developing countries like Myanmar where the country-specific information about MSW is not sufficiently available. By IPCC default method [16], the methane emissions from open dumpsites and landfills were esti- mated as described in Eq. (5):

$$
\begin{aligned}
& \mathrm{CH}_{4} \text { Emission }= \\
& {\left[\left(\begin{array}{c}
M S W_{T} \times M S W_{F} \times M C F \times \\
D O C \times D O C_{F} \times F \times\left(\frac{16}{12}\right)-R
\end{array}\right) \times(1-O X)\right]}
\end{aligned}
$$

Where $\mathrm{CH}_{4}$ Emission is methane emission from landfill in gigagrams per year;

$M S W_{T}$ is the total solid waste generation (Gg per year);

$M S W_{F}$ is the fraction of solid waste disposed in wet weight basis;

$M C F$ is the methane correction factor (0.8 and 1 as a recommended value of IPCC for the unmanaged landfills and managed landfills, respectively);

DOC is degradable organic carbon in MSW (0.1042, derived from IPCC default DOC values);

$D O C_{F}$ is the fraction of DOC that can decompose (fraction) (0.5 as a default value of IPCC);

$F$ is fraction of $\mathrm{CH}_{4}$ in generated landfill gas ( 0.5 as a default value of IPCC);

$R$ is recovered methane (Gg per year) (zero for open dumpsites with no gas collection system);

$16 / 12$ is the molecular weight ratio of methane to carbon;

$O X$ is the oxidation factor, $(0.10$ and 0.00 for sanitary landfills with landfill covers and open dumpsites, respectively as a recommended value of IPCC;

$\mathrm{CH}_{4}$ emissions are converted to be 21 times higher than carbon dioxide equivalents $\left(\mathrm{CO}_{2}\right.$-eq) on a 100 year time horizon basis $[13,16]$.

\subsubsection{GHG emission from transportation}

Fuel consumption for waste transportation towards the open dumping and landfills in all the cities of Myanmar was approximately derived from the waste transportation data of Yangon city. In Yangon city, 128,704 liters of diesel and 900 liters of gasoline were used for transporting 46,500 tons of collected wastes per month in 2012 [6].

Based on the IGES GHG calculation methods [15], GHG emissions from fossil fuel based-transportation of wastes to final disposal sites were estimated as follows [13]:

$$
G H G_{T}=\frac{F}{W} \times E C_{f f} \times E F
$$

Where

$G H G_{T}$ is $\mathrm{GHG}$ emissions from transportation $\left(\mathrm{kg} \mathrm{CO}_{2}\right.$ per ton of transported waste);

$F$ is total amount of fossil fuel consumption per month, (Diesel in liters and Natural gas in $\mathrm{kg}$ );

$W$ is total amount of waste transported per month (tons per month);

$E C_{f f}$ is the energy content of fossil fuel (Diesel: $36.42 \mathrm{MJ}$ per liter; Natural gas: $37.92 \mathrm{MJ}$ per $\mathrm{kg}$ );

$E F$ is $\mathrm{CO}_{2}$ emission factor of the fuel (Diesel: $0.074 \mathrm{~kg} \mathrm{CO}_{2}$ per MJ; Natural gas: $0.056 \mathrm{~kg} \mathrm{\textrm {CO } _ { 2 }}$ per MJ) [15].

Waste transportation at the waste disposal sites (waste-to-en- 
ergy plants, composting facilities, landfills, etc.) was considered to be of equal distance from waste disposal at open dumpsites for estimation of GHG emissions from the waste transportation sector.

\section{Results and Discussion}

In this study, the annual amount of GHG emissions from open dumping was estimated at 130 and $155 \mathrm{Gg}$ of $\mathrm{CH}_{4}$ per year in 2018 and 2020, respectively. However, Thein's study [12] reported that the annual estimated GHG emissions from waste disposal at open dumpsites in Myanmar amounted to approximately 180 and $190 \mathrm{Gg}$ of $\mathrm{CH}_{4}$ per year in 2018 and 2020, respectively. Therefore, Thein's study had 25\% and 20\% higher GHG emission potential than this study in 2018 and 2020, respectively.

Likewise, the recent study by the scholars [13] estimated that the annual GHG emissions from open dumping in Yangon, the major city of Myanmar, amounted to 26 and $31 \mathrm{Gg}$ of $\mathrm{CH}_{4}$ per year in 2018 and 2020, respectively. The study used multilinear regression model (a correlation of urban population, GDP and solid waste generation) and IPCC calculation method to estimate the annual solid waste generation and GHG emissions from waste disposal of Yangon for the year 2015-2025. Based on the research studies [5, 8], the waste generation rate in Yangon accounted for approximately $25 \%$ of the total waste generation rates in Myanmar in 2015. While Yangon was considered to contribute 25\% of the total waste generation rates of Myanmar, the annual estimated amount of GHG emissions from open dumping in the present study amounted to approximately 27 and $33 \mathrm{Gg}$ of $\mathrm{CH}_{4}$ per year in 2018 and 2020, respectively. Therefore, it was observed that the recent study [13] had 4\% and 5\% lower GHG emissions than the present study. Overall, the estimated GHG emission values of the present study related to waste disposal at open dumpsites ranged within these of two studies, regarding Thein's study [12] and the recent study by the scholars [13].

A comparison of the GHG emissions and avoidance of the different waste disposal methods in Myanmar is presented in Fig. 6. Regarding the GHG emissions from the landfills and open dumpsites, landfilling (by 75\% of the total waste disposal methods) could generate approximately 10\% higher GHG emissions than open dumping (by $83 \%$ of the total waste disposal methods) in 2018 as shown in Fig. 6(a) and Fig. 6(b). It was probably due to the well-managed collecting systems of GHG emissions in landfills that can accumulate higher than in open dumpsites. However,
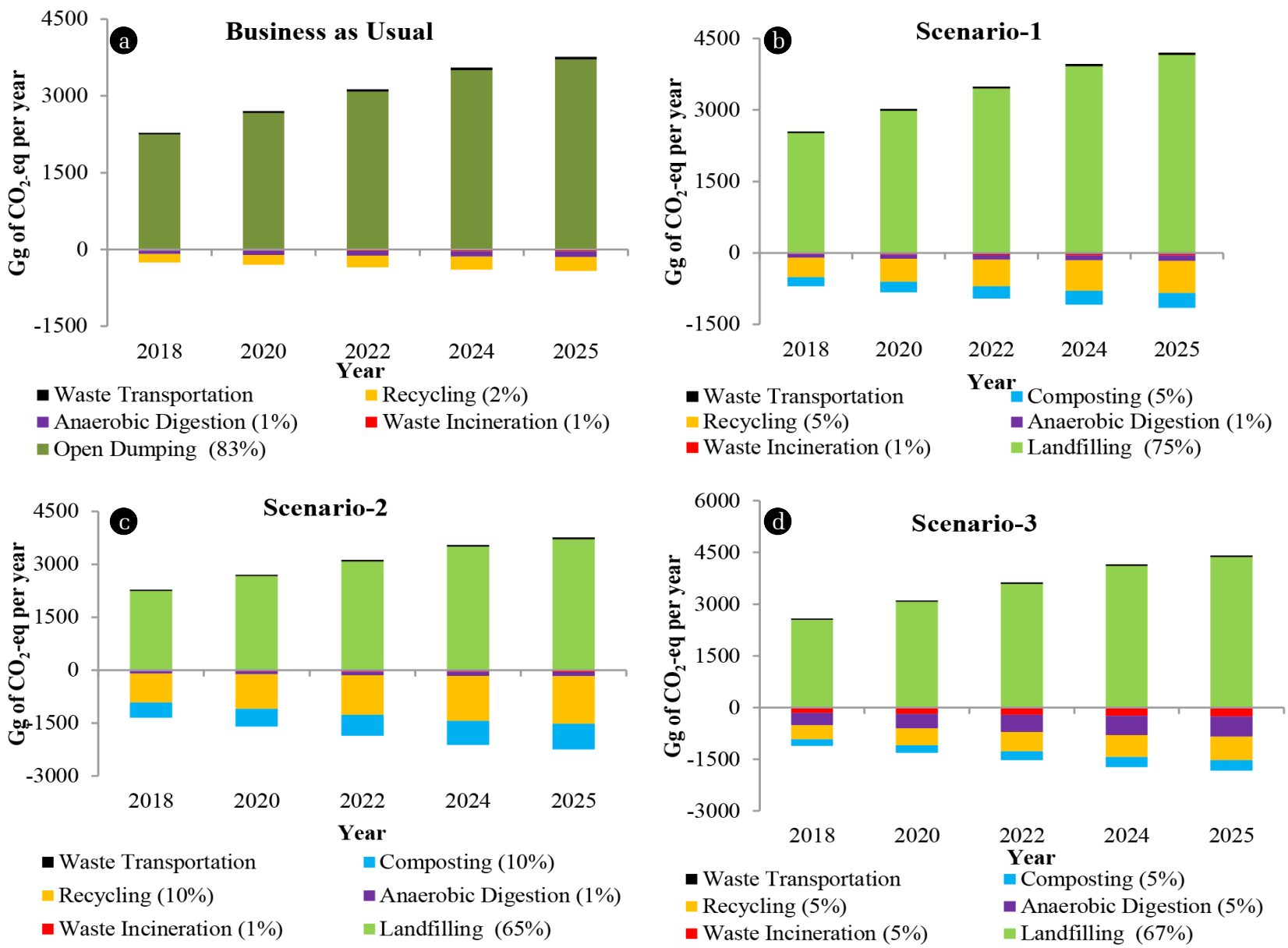

Fig. 6. A comparison of GHG emissions and avoidance of different waste disposal methods by (a) Business-as-usual (b) Scenario-1 (c) Scenario-2 and (d) Scenario-3. 

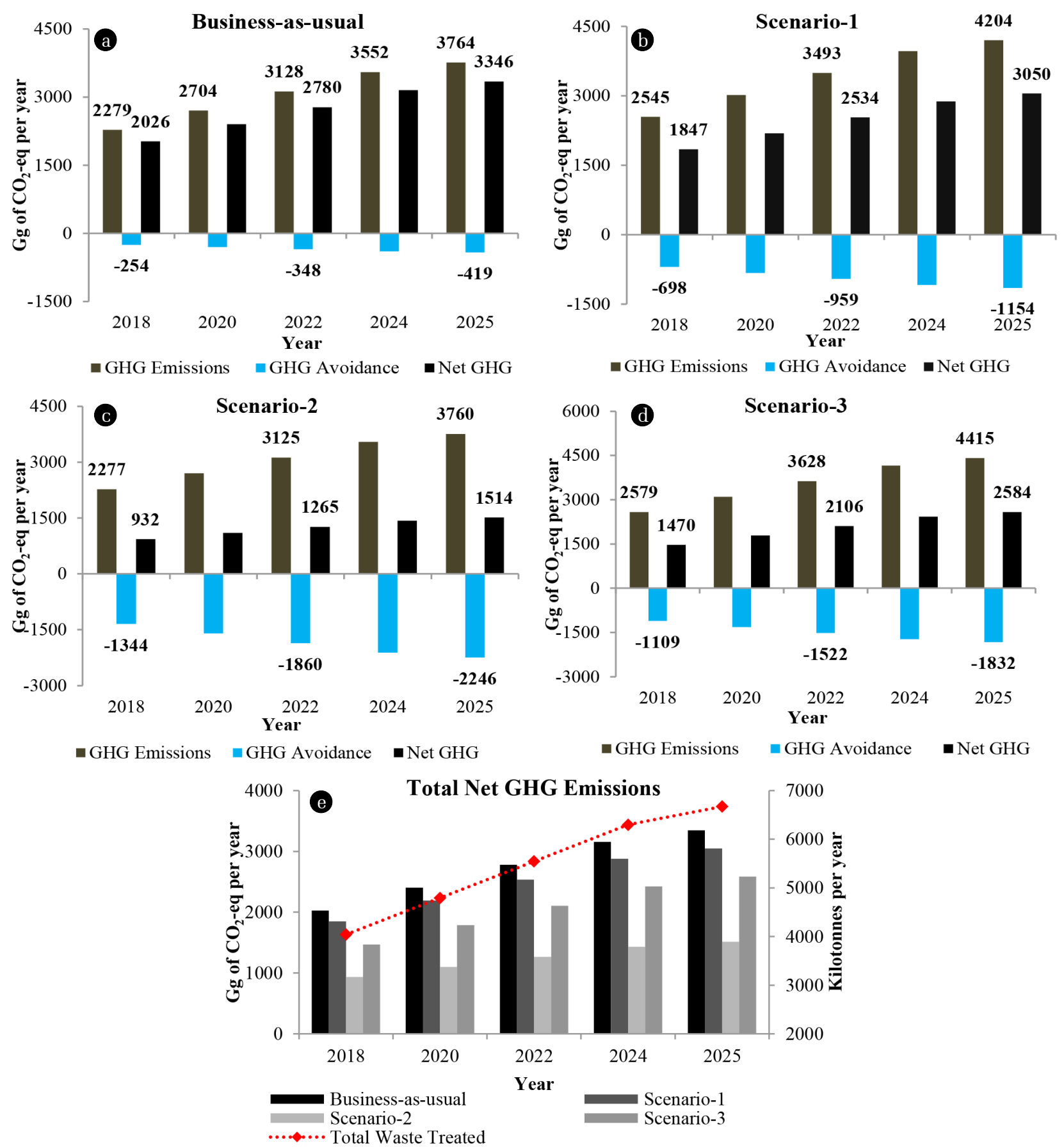

Fig. 7. Comparison of net GHG emissions and avoidance of waste management by (a) Business-as-usual (b) Scenario-1 (c) Scenario-2 (d) Scenario-3 and (e) Total net GHG emissions.

the landfill considered in this study was a type of landfill without gas recovery systems. Therefore, landfills with gas recovery systems might be probably offering more benefits in energy and environments especially in developing countries that could not currently afford the costly waste-to-energy technologies such as waste incineration and gasification. However, it is remarked that only 3Rs activities are the best waste management practices to reduce waste disposal at open dumping and landfills and to minimize the GHG emissions from the waste management sector. In Fig. 6(a) and Fig. 6 (c), it could be seen that $10 \%$ recycling rates of Scenario- 2 could reduce $35 \%$ of the GHG emissions of open dumping from business-as-usual practices in 2018. 
Table 1. Comparison of the Waste Disposal Methods

\begin{tabular}{|c|c|c|c|c|c|c|c|}
\hline $\begin{array}{l}\text { Waste disposal } \\
\text { methods }\end{array}$ & $\begin{array}{l}\text { Separation } \\
\text { work }\end{array}$ & Cost & $\begin{array}{l}\text { Working skills } \\
\text { and technologies }\end{array}$ & $\begin{array}{l}\text { Availability of } \\
\text { raw material } \\
\text { resources }\end{array}$ & $\begin{array}{l}\text { Energy } \\
\text { benefits }\end{array}$ & $\begin{array}{l}\text { Economic } \\
\text { benefits }\end{array}$ & $\begin{array}{c}\text { Environmental } \\
\text { impact }\end{array}$ \\
\hline Business-as-usual & As-usual & Low & Normal & Low & Average & Average & High \\
\hline Scenario-1 & Needed & Low & Normal & High & Average & Average & $\begin{array}{c}\text { Comparatively } \\
\text { lower }\end{array}$ \\
\hline Scenario-2 & $\begin{array}{l}\text { Highly } \\
\text { needed }\end{array}$ & High & Highly needed & $\begin{array}{c}\text { Comparatively } \\
\text { higher }\end{array}$ & High & High & $\begin{array}{c}\text { Comparatively } \\
\text { much lower }\end{array}$ \\
\hline Scenario-3 & $\begin{array}{l}\text { Highly } \\
\text { needed }\end{array}$ & $\begin{array}{l}\text { Comparatively } \\
\text { higher }\end{array}$ & Highly needed & $\begin{array}{c}\text { Comparatively } \\
\text { higher }\end{array}$ & $\begin{array}{c}\text { Comparatively } \\
\text { higher }\end{array}$ & High & $\begin{array}{c}\text { Comparatively } \\
\text { much lower }\end{array}$ \\
\hline
\end{tabular}

Fig. 7 shows a comparison of the net GHG emissions and avoidance from the MSW management by business-as-usual and three scenarios in Myanmar. As business-as-usual, it was estimated that the waste management sector of Myanmar generated approximately 2,300 $\mathrm{Gg}$ of $\mathrm{CO}_{2}$-eq per year and saved around $250 \mathrm{Gg}$ of $\mathrm{CO}_{2}$-eq per year in 2018 (Fig. 7(a)). Meanwhile, the amount of annual GHG emissions and avoidance in 2018 were estimated at around 2,550 and $700 \mathrm{Gg}$ of $\mathrm{CO}_{2}$-eq per year by Scenario-1, 2,300 and 1,350 $\mathrm{Gg}$ of $\mathrm{CO}_{2}$-eq per year by Scenario-2, and 2,600 and 1,100 Gg of $\mathrm{CO}_{2}$-eq per year by Scenario-3, respectively (Fig. 7(a), Fig. 7(b), Fig. 7(c) and Fig. 7(d)). Besides, the total amount of annual net GHG emissions by business-as-usual, Scenario-1, Scenario-2 and Scenario-3 was estimated at 2,000, 1,850, 900 and 1,500 $\mathrm{Gg}$ of $\mathrm{CO}_{2}$-eq per year in 2018, trending around 3,350, $3,050,1,500$ and $2,600 \mathrm{Gg}$ of $\mathrm{CO}_{2}$-eq per year in 2025, respectively.

It was observed that Scenario-2 contributed the lowest GHG emissions among the waste disposal methods, followed by Scenario-3 (Fig. 7(e)). With the lowest GHG emissions, Scenario-2 highlighted the least impact on the environment and public health in Myanmar. The reason for the lowest GHG emissions by this scenario was due to that, since it constituted $10 \%$ recycling rates and $10 \%$ composting process, the recycling sector could save a large amount of GHG emissions not only from the material production from the virgin process of recyclables but also from saving the material resources that are rare to be exploited. Therefore, recycling is commonly referred as one of the best waste disposal methods in MSW management after prevention, reduce and reuse activities. However, to achieve such a proposed recycling rate, Myanmar will need to improve waste separation and collection services. Since separation work needs public participation and private sector involvement, local government will not only need to cooperate with private sectors but also will need to educate the public about waste management through training centers and schools.

At the same time, since composting process is among the lowest cost waste disposal methods, an efficient waste separation-and-collection system is a must to gain the high-quality compost for agricultural use. By granting the sufficient fund by the local government of Myanmar, the local research institutions and universities could do more research on the locally accessible technologies based on the developed technologies in the other countries.

The comparison of the business-as-usual waste management and the proposed waste disposal scenarios is presented in Table 1. As a comparison of the waste disposal methods, the require- ments, benefits and impacts of each waste disposal option are described. Out of them, separation work represents separation of wastes that are needed to gain high-quality raw wastes for the specific waste disposal methods. Cost refers to the capital cost, maintenance and operation cost. Working skills and technologies will be required depending on the technologies applied; in some cases, highly qualified technicians and consultants will be needed. Availability of raw materials will include agriculture resource from compost and recyclable materials from recycling sector and incineration. Energy benefits may include the energy (thermal, electricity, fuel, etc.) from waste incineration and anaerobic digestion. Economic benefits will account for the job opportunities for local people and waste pickers, and creation of ways of revenue generation to all the stakeholders in waste management process chain [7]. Environmental impact will include the impacts of each waste disposal method on the environment such as air pollution, water pollution and soil pollution.

As the overall benefits, it was observed that the Scenario-2 and Scenario-3 could offer the lower GHG emissions and the higher resource recovery among the waste disposal methods. However, while the costs related to these two waste disposal scenarios were roughly compared, Scenario-3 might have the comparatively higher capital cost and maintenance-and-operation cost for its waste to energy technologies (incineration and anaerobic digestion) than Scenario-2. Therefore, Scenario-2 appeared to be much more beneficial for the MSW management sector of Myanmar. And it also had the least environmental impacts, being around $40 \%$ less GHG emission than Scenario-3. However, as described earlier, these scenarios would need the improvement of the waste collection and treatment systems, private sector involvement, public participation and work of research institutions. Therefore, if the local governments could efficiently cooperate with the public, private sectors, research institutions and non-government organizations, the targets of these similar scenarios could be achieved in the years to come.

Overall, the hypothetical scenarios in the study conveyed an alternative approach to the waste management of Myanmar for highlighting the GHG emission potential from the business-as-usual practices and the proposed scenarios. Therefore, the proposed scenarios might become a very important approach to the waste management system of a developing country, like Myanmar, that has not fully tackled the environmental and public health issues related to the waste management sector, yet. As 
a result, the study has supported the technical and environmental points of view to contribute a good motivation towards the future waste management systems of Myanmar and the other developing countries in order to take a more efficient forward step from the current situations. Besides, the study is also supposed to be a great help to tackle the local and global issues related to the environmental impacts of waste management in the developing countries.

Nowadays, waste-to-energy has become a favorable option to gain environmental and economic benefits in the developing countries. Therefore, the future research related to this study could be exploring the possibilities of the energy unitizations of municipal solid wastes as clean energy sources by improving the solid waste quality improvement in Myanmar. The improvement methods will be considered as solar drying, thermal drying with waste heat, biodrying and a combined drying system.

\section{Conclusions}

The major waste disposal methods in Myanmar are recycling, waste incineration, anaerobic digestion and landfills. Out of them, open dumping accounts for the most predominant waste disposal method. The current waste management sector of Myanmar generates approximately 2,000 $\mathrm{Gg}$ of $\mathrm{CO}_{2}$-eq per year in 2018, trending around $3,350 \mathrm{Gg}$ of $\mathrm{CO}_{2}$-eq per year in 2025. While three hypothetical scenarios were taken into account as an alternative approach to waste management of Myanmar, a total amount of annual net GHG emissions by Scenario-1, Scenario-2 and Scenario-3 would generate around 1,850,900 and 1,500 $\mathrm{Gg}$ of $\mathrm{CO}_{2}$-eq per year in 2018, trending around 3,050, 1,500 and 2,600 $\mathrm{Gg}$ of $\mathrm{CO}_{2}$-eq per year in 2025, respectively. Among them, the Scenario-2 $(10 \%$ recycling, $10 \%$ composting, $65 \%$ landfilling and the currently applied waste-to-energy power plants) could offer the least environmental impacts, along with the lowest GHG emissions and the highest waste resource recovery. The GHG emissions from the business-as-usual waste management could be reduced by $50 \%$ by this scenario during 2018-2025. Therefore, if the local governments in Myanmar could efficiently cooperate with the public, private sectors, research institutions and non-government organizations, these achievable similar scenarios could be implemented for reducing the environmental impacts and increasing the waste resource recovery in the years to come.

\section{Acknowledgments}

The author would like to express his sincere gratitude to the Ministry of Education, Youth and Sports of the Czech Republic for the financial support to the Sustainable Development in Myanmar. He is also so grateful to Ministry of Education of Myanmar for giving him a chance to study in the Czech Republic.

\section{Nomenclature}

The avoided GHG emission from equivalent amount of material production from virgin process of component, i, in the recyclable materials, $\mathrm{kgCO}_{2}$-eq per ton

AC The amount of compost produced, ton of compost per ton of waste

$\mathrm{AD}_{\text {avoidance }}$ The GHG avoidance due to the energy recovery from anaerobic digestion and due to avoidance of landfilling of the equivalent amount of organic wastes used for anaerobic digestion, $\mathrm{kg} \mathrm{CO}_{2}$ per ton of organic

$\mathrm{AD}_{\text {emission }} \quad$ The GHG emissions from the treatment of anaerobic digestion, $\mathrm{kg} \mathrm{CO}_{2}$ per ton of organic waste

$\mathrm{C}_{\text {avoidance }} \quad$ The GHG avoidance from replacement of the equivalent amount of chemical fertilizer use and due to avoidance of landfilling of the equivalent amount of organic wastes used for composting, $\mathrm{kg} \mathrm{CO}_{2}$ per ton of organic wastes

$\mathrm{C}_{\text {emission }} \quad$ The GHG emissions from composting process, $\mathrm{kg}$ $\mathrm{CO}_{2}$ per ton of organic waste

$\mathrm{CF}_{\mathrm{i}} \quad$ The fraction of carbon in the dry matter (total carbon content)

$\mathrm{C}_{\text {Biogas }} \quad$ The collected amount of biogas, $\mathrm{m}^{3}$ per ton of organic waste

$\mathrm{dm}_{\mathrm{i}} \quad$ The dry matter content in the waste (partially wet weight) incinerated waste

DM The dry matter percentage in the influent, \%

DOC Degradable organic carbon in municipal solid waste

DOC $_{\mathrm{F}} \quad$ The fraction of degradable organic carbon

$\mathrm{E}_{\mathrm{CH} 4}$

$\mathrm{E}_{\mathrm{CO} 2}$

$\mathrm{E}_{\text {ferCH4 }}$

$\mathrm{E}_{\mathrm{ferCO} 2}$

$\mathrm{E}_{\text {ferN2O }}$

$\mathrm{E}_{\mathrm{i}} \quad \mathrm{GHG}$ emission from recycling of component; $i$, in The emissions of $\mathrm{CH}_{4}, \mathrm{~kg}$ of $\mathrm{CH}_{4}$ per ton of waste The combustion emissions to generate one $\mathrm{kWh}$ of the electricity, $\mathrm{kg}$ of $\mathrm{CO}_{2}$ per $\mathrm{kWh}$

The emissions of $\mathrm{CH}_{4}$ due to chemical fertilizer use, $0.00338 \mathrm{~kg}$ of $\mathrm{CH}_{4}$ per ton of compost

The emissions of $\mathrm{CO}_{2}$ due to chemical fertilizer use, $\mathrm{kg}$ of $\mathrm{CO}_{2}$ per ton of compost The emissions of $\mathrm{N}_{2} \mathrm{O}$ due to chemical fertilizer use, $0.0685 \mathrm{~kg}$ of $\mathrm{N}_{2} \mathrm{O}$ per ton of compost the recyclable materials, $\mathrm{kgCO}_{2}$-eq per ton

$\mathrm{E}_{\mathrm{N} 2 \mathrm{O}} \quad$ The emissions of $\mathrm{N}_{2} \mathrm{O}, \mathrm{kg}$ of $\mathrm{N}_{2} \mathrm{O}$ per ton of waste

$\mathrm{EC}_{\mathrm{CH} 4} \quad$ The energy content of $\mathrm{CH}_{4}, \mathrm{MJ}$ per $\mathrm{m}^{3}$

$\mathrm{EF}_{\mathrm{CO} 2} \quad$ The emission factor of $\mathrm{CO}_{2}$ by combustion of liquid petroleum gas (LPG), $\mathrm{kg}$ of $\mathrm{CO}_{2}$ per MJ

$\mathrm{EC}_{\mathrm{ff}} \quad$ The energy content of fossil fuel, MJ per liter/ MJ per $\mathrm{kg}$

EF $\quad \mathrm{CO}_{2}$ emission factor of the fuel, $\mathrm{kgCO}_{2}$ per $\mathrm{MJ} /$ $\mathrm{kg} \mathrm{CO}_{2}$ per MJ

$\mathrm{F} \quad$ Fraction of $\mathrm{CH}_{4}$ in generated landfill gas/total amount of fossil fuel consumption per month, liters $/ \mathrm{kg}$

$\mathrm{FCF}_{\mathrm{i}} \quad$ The fraction of fossil carbon in the total carbon

Gelectricity The generated electricity from incineration plant, kWh per ton of waste GDP gross domestic product

$\mathrm{GHG}_{\mathrm{LFavoidance}}$ The GHG avoidance of landfilling, $\mathrm{kg} \mathrm{CO}_{2}$ per ton of waste

$\mathrm{GHG}_{\mathrm{T}} \quad \mathrm{GHG}$ emissions from transportation, $\mathrm{kg} \mathrm{CO}_{2}$ per ton of transported waste 


\begin{tabular}{|c|c|}
\hline $\mathrm{GWP}_{\mathrm{CH} 4}$ & $\begin{array}{l}\text { The global warming potential of } \mathrm{CH}_{4}, \mathrm{~kg} \mathrm{CO} \text { per } \\
\mathrm{kg} \text { of } \mathrm{CH}_{4}\end{array}$ \\
\hline $\mathrm{GWP}_{\mathrm{N} 2 \mathrm{O}}$ & $\begin{array}{l}\text { The global warming potential of } \mathrm{N}_{2} \mathrm{O}, \mathrm{kg} \mathrm{CO}_{2} \text { per } \\
\mathrm{kg} \text { of } \mathrm{N}_{2} \mathrm{O}\end{array}$ \\
\hline $\mathrm{i}$ & $\begin{array}{l}\text { The type of fossil based waste incinerated such } \\
\text { as textiles, rubber and leather, plastics/component } \\
\text { in the recyclable materials }\end{array}$ \\
\hline $\mathrm{I}_{\text {avoidance }}$ & $\begin{array}{l}\text { The GHG avoidance from replacement of equiv- } \\
\text { alent amount of conventional electricity }\end{array}$ \\
\hline$I_{\text {emission }}$ & $\begin{array}{l}\text { The GHG emissions from combustion of wastes, } \\
\mathrm{kg} \mathrm{CO}_{2} \text { per ton of waste }\end{array}$ \\
\hline $\mathrm{L}_{\mathrm{i}}$ & $\begin{array}{l}\text { The avoided GHG emission from landfilling of com- } \\
\text { ponent, i, in the recyclable materials, } \mathrm{kgCO}_{2} \text {-eq } \\
\text { per ton }\end{array}$ \\
\hline $\mathrm{MSW}_{\mathrm{T}}$ & The total solid waste generation, Gg per year \\
\hline $\mathrm{MSW}_{\mathrm{F}}$ & $\begin{array}{l}\text { The fraction of solid waste disposed in wet weight } \\
\text { basis }\end{array}$ \\
\hline $\mathrm{n}$ & The number of recyclable materials \\
\hline $\mathrm{NGHG}_{\mathrm{AD}}$ & $\begin{array}{l}\text { The net GHG emission/avoidance from anaerobic } \\
\text { digestion, } \mathrm{kg} \mathrm{CO}_{2} \text { per ton of organic }\end{array}$ \\
\hline $\mathrm{NGHG}_{\mathrm{C}}$ & $\begin{array}{l}\text { The net GHG emission/avoidance from compost- } \\
\text { ing, } \mathrm{kg} \mathrm{CO}_{2} \text { per ton of waste }\end{array}$ \\
\hline $\mathrm{NGHG}_{\mathrm{I}}$ & $\begin{array}{l}\text { The net GHG emission/avoidance from in- } \\
\text { cineration, } \mathrm{kg} \mathrm{CO}_{2} \text { per ton of waste }\end{array}$ \\
\hline $\mathrm{NGHG}_{\mathrm{R}}$ & $\begin{array}{l}\text { The net GHG emission rom the recycling sector, } \\
\mathrm{kgCO}_{2} \text {-eq per ton }\end{array}$ \\
\hline $\mathrm{OF}_{\mathrm{i}}$ & The oxidation factor \\
\hline OX & The oxidation factor \\
\hline $\mathrm{P}_{\mathrm{CH} 4}$ & The percentage of $\mathrm{CH}_{4}$ in biogas, \% \\
\hline $\mathrm{PC}_{\mathrm{Agr}}$ & $\begin{array}{l}\text { The percentage of compost use for agricultural } \\
\text { and gardening purpose, } \%\end{array}$ \\
\hline $\mathrm{R}$ & Recovered methane, Gg per year \\
\hline $\mathrm{R}_{\mathrm{i}}$ & $\begin{array}{l}\text { The composition of component, } \mathrm{i} \text {, in the recyclable } \\
\text { materials }(\%) \text { and } \mathrm{n} \text { is the number of recyclable } \\
\text { materials }\end{array}$ \\
\hline $\mathrm{SW}_{\mathrm{i}}$ & $\begin{array}{l}\text { The total amount of solid waste of type i (wet } \\
\text { weight) incinerated, kg per ton of waste }\end{array}$ \\
\hline W & $\begin{array}{l}\text { Total amount of waste transported per month, tons } \\
\text { per month }\end{array}$ \\
\hline
\end{tabular}

\section{References}

1. Worldometers. Population of Myanmar (2018 and historical) and Myanmar Population Forecast. Worldometers; c2018 [cited 12 October 2018] Available from: http://www.worldometers. info/world-population/myanmar-population/.

2. Knomea. GDP per capita by country, Statistics from IMF, 1980-2023. Knomea; c2018 [citied 12 October 2018]. Available from: https://knoema.com/pjeqzh/gdp-per-capita-by-countrystatistics-from-imf-1980-2023?country=Myanmar.

3. Statista. Myanmar: Urbanization from 2007 to 2017. Statista; c2018 [cited 12 October 2018]. Available from: https:/ www.statista.com/statistics/526518/urbanization-in-myanmar/.

4. Mann U, Myint O. Myanmar participants. Community-based 3Rs practices in Myanmar. Mann and Myint; c2018 [cited
12 October 2018] http://www.iges.or.jp/en/archive/wmr/pdf/ .../6_Myanmar_Day1_Session2.pdf.

5. Premakumara DGJ, Hengesbaugh M, Onogawa K, Hlaing OMT. Waste management in Myanmar: Current status, key challenges and recommendations for national and city waste management strategies. Institute for Global Environmental Strategies (IGES). Japan; 2017.

6. Institute for Global Environmental Strategies (IGES). Commission report: Supporting low-carbon Yangon city through Joint Crediting Mechanism (JCM) project formulation, March 2014. IGES; c2018. [cited 12 October 2018]. Available from: http://www.env.go.jp/earth/coop/lowcarbonasia/english/project/ data/EN_MMR_2013_01.pdf.

7. Menikpura N. Sustainable consumption and production (SCP) group institute for global environmental strategies (IGES). Integrated solid waste management: Towards low-carbon waste management in Yangon-Myanmar. International workshop on sustainable waste management in Yangon. Menikpura; c2018. [cited 12 October 2018]. Available from: https://www. researchgate.net/publication/271768787_Integrated_waste_ management_Towards_low_carbon_waste_management_in_Yangon-Myanmar.

8. Hoornweg D, Bhada-Tata P. What a waste: A global review of solid waste management. Urban development series knowledge papers no. 15. 2012. p. 1-98.

9. Messenger B. JFE engineering to build first waste to energy plant Myanmar, 2017. Messenger B; c2018 [cited 12 October 2018]. Available from: https://waste-management-world.com/a/ jfe-engineering-to-build-first-waste-to-energy-plant-myanmar.

10. Ngoc UN, Schnitzer H. Sustainable solutions for solid waste management in Southeast Asian countries. Waste Manage. 2009;29:1982-1995.

11. UNEP. Global waste management outlook [Internet]. United Nations Environment Programme 2015; [cited 8 September 2015]. Available from: file:///C:/Users/ghye0/Downloads/-Global_ Waste_Management_Outlook-2015Global_Waste_Manageme nt_Outlook.pdf.pdf.

12. Thein M. Member of GHG inventory and Mitigation group, Initial National Communication Project for UNFCCC, Myanmar: GHG emissions from waste sector of INC of Myanmar. In: Proceedings of the 8th Workshop on GHG Inventories in Asia (WGIA8), 13-16 July 2010; Laos, Vientiane.

13. Tun MM, Juchelková D. Assessment of solid waste generation and greenhouse gas emission potential in Yangon city, Myanmar. J. Mater. Cycles Waste Manage. 2018;20:1397-1408.

14. Tun MM, Juchelková D, Raclavská H, Sassmanová V. Utilization of biodegradable wastes as a clean energy source in the developing countries: A case study in Myanmar. Energies 2018;11:3183.

15. Menikpura N, Sang-Arun J. User manual: Estimation tool for greenhouse gas (GHG) emissions from municipal solid waste (MSW) management in a life cycle perspective. Institute for Global Environmental Strategies, 2013. Menikpura N and Sang-Arun J; c2018 [cited 12 October 2018]. Available from: https://mafiadoc.com/ghg-emissions-from-municipal-solid-waste_59ca4ca51723ddbc3033c198.html.

16. Intergovernmental Panel on Climate Change (1996) IPCC 
Guideline for National Green House Gas Inventories Workbook. IPCC; c2017 [cited 12 Mar 2017]. Available from: http://www.ipcc-nggip.iges.or.jp/public/gl/invs5.htm.

17. IPCC 2008. 2006 IPCC guidelines for national greenhouse gas inventories - A primer. Prepared by the National Greenhouse Gas Inventories Programme. In: Eggleston HS, Miwa K, Srivastava N, Tanabe K, eds. Japan: IGES; 2008. p. 1-20.

18. The ABC of Integrated Waste Management; c2018 [cited 12
October 2018]. Available from: http://www.seas.columbia.edu/ earth/wtert/wtertfaq.html.

19. Environmental Protection Agency (EPA). Energy and the Environment. Greenhouse gases equivalencies calculator Calculations and references. EPA; c2018 [cited 16 October 2018]. Available from: https://www.epa.gov/energy/greenhouse-gases-equivalencies-calculator-calculations-and-references. 